\title{
Acid Efflux from Retinal Glial Cells Generated by Sodium Bicarbonate Cotransport
}

\author{
Eric A. Newman \\ Department of Physiology, University of Minnesota, Minneapolis, Minnesota 55455
}

\begin{abstract}
Sodium bicarbonate cotransport was studied in freshly dissociated Müller cells of the salamander retina. Variations in intracellular and extracellular $\mathrm{pH}$ evoked by elevating extracellular potassium concentration $\left(\left[\mathrm{K}^{+}\right]_{0}\right)$ were recorded. Intracellular $\mathrm{pH}$ was measured by standard ratio imaging of the $\mathrm{pH}$-sensitive dye BCECF, whereas extracellular $\mathrm{pH}$ was monitored by imaging BCECF fixed to coverslips under dissociated cells. Increasing $\left[\mathrm{K}^{+}\right]_{0}$ from 2.5 to $50 \mathrm{~mm}$ resulted in an intracellular alkalinization. The rate of alkalinization, $0.047 \mathrm{pH}$ units $/ \mathrm{min}$, was reduced to $42 \%$ of control when HEPES was substituted for $\mathrm{HCO}_{3}^{-}$and was reduced to $36 \%$ of control by the addition of $0.5 \mathrm{~mm}$ DIDS, a Na${ }^{+} / \mathrm{HCO}_{3}^{-}$cotransport blocker. The $\mathrm{K}^{+}$-evoked alkalinization was $\mathrm{Cl}^{-}$-independent and was not substantially reduced by amiloride or bumetanide. Increasing $\left[\mathrm{K}^{+}\right]_{0}$ to $50 \mathrm{~mm}$ also produced a rapid extracellular acidification, 0.01 to $0.05 \mathrm{pH}$ units in amplitude. HEPES substitu-
\end{abstract}

tion and addition of $0.5 \mathrm{~mm}$ DIDS reduced the acidification to $7-8 \%$ of control, respectively. These results confirm the presence of a $\mathrm{Na}^{+} / \mathrm{HCO}_{3}^{-}$cotransport system in salamander Müller cells and provide definitive evidence that glial cells can generate an extracellular acidification when $\left[\mathrm{K}^{+}\right]_{0}$ is increased.

The $\mathrm{K}^{+}$-evoked extracellular acidification measured beneath cell endfeet was $304 \%$ of the amplitude of the acidification beneath cell somata, confirming that cotransporter sites are preferentially localized to the endfoot. The carbonic anhydrase inhibitor benzolamide $\left(2 \times 10^{-5} \mathrm{M}\right)$, which is poorly membrane permeant, increased the $\mathrm{K}^{+}$-evoked extracellular acidification to $269 \%$ of control, demonstrating that salamander Müller cells possess extracellular carbonic anhydrase.

Key words: glial cell; Müller cell; retina; $\mathrm{Na}^{+} / \mathrm{HCO}_{3}^{-}$cotransport; $\mathrm{pH}$; BCECF; salamander
Neuronal activity in the central nervous system (CNS) typically results in a transient alkalinization of extracellular space followed by a sustained acidification (Chesler, 1990; Chesler and Kaila, 1992). The transient alkalinization is associated with synaptic activity and is generated by the activation of both glutamatergic and GABAergic receptors (Jarolimek et al., 1989; Chen and Chesler, 1992b; Kaila et al., 1992). In contrast, the sustained acidification can be generated in the absence of synaptic activation (Ransom et al., 1988) and may be caused by acid efflux (Sykova and Svoboda, 1990) as well as by the release of $\mathrm{CO}_{2}$ (Voipio and Kaila, 1993) from activated neurons.

These activity-dependent variations in extracellular $\mathrm{pH}\left(\mathrm{pH}_{\mathrm{o}}\right)$ may significantly influence neuronal activity (Balestrino and Somjen, 1988; Taira et al., 1993; Gottfried and Chesler, 1994). For example, $\mathrm{pH}_{\mathrm{o}}$ modulates synaptic transmission (Balestrino and Somjen, 1988; Jarolimek et al., 1989; Taira et al., 1993; Gottfried and Chesler, 1994). NMDA receptor conductance is strongly dependent on $\mathrm{pH}_{\mathrm{o}}$, with proton concentration modulating the kinetics of channel gating (Tang et al., 1990; Traynelis and CullCandy, 1990). Similarly, protons block voltage-dependent $\mathrm{Ca}^{2+}$ channels (Prod'hom et al., 1987; Krafte and Kass, 1988; Barnes and Bui, 1991; Klockner and Isenberg, 1994) and modulate synaptic transmission by reducing $\mathrm{Ca}^{2+}$ influx at presynaptic terminals (Barnes et al., 1993). A dramatic example of $\mathrm{pH}_{\mathrm{o}}$ modulation

\footnotetext{
Received June 12, 1995; revised Sept. 5, 1995; accepted Sept. 20, 1995.

This work was supported by NIH Grant EY-04077. I thank Vincent A. Barnell for his assistance in measuring the excitation and emission spectra of dextran-BCECF and Janice I. Gepner and Kathleen R. Zahs for their helpful comments on the manuscript.

Correspondence should be addressed to Dr. Eric A. Newman, 6-255 Millard Hall, Department of Physiology, University of Minnesota, 435 Delaware Street SE, Minneapolis, MN 55455 .

Copyright (C) 1995 Society for Neuroscience $0270-6474 / 95 / 160159-10 \$ 05.00 / 0$
}

of synaptic efficacy is provided by the retina, in which synaptic transmission between photoreceptors and second-order cells is reduced substantially by extracellular acidification (Harsanyi and Mangel, 1993; Kleinschmidt, 1994); in one preparation by $24 \%$ when $\mathrm{pH}_{\mathrm{o}}$ is reduced by just $0.05 \mathrm{pH}$ units (Barnes et al., 1993).

Glial cells in the CNS may contribute to the extracellular acidification initiated by neuronal activity. Several types of glial cells possess an electrogenic $\mathrm{Na}^{+} / \mathrm{HCO}_{3}^{-}$cotransport system (Astion and Orkand, 1988; Kettenmann and Schlue, 1988; Newman, 1991; O'Connor et al., 1994). The activity of the cotransporter is modulated by changes in cell membrane potential (Boron and Boulpaep, 1983, 1989). Neuronal activity increases extracellular potassium concentration $\left(\left[\mathrm{K}^{+}\right]_{n}\right)$, which depolarizes glial cells and intensifies the transport of $\mathrm{Na}^{+}$and $\mathrm{HCO}_{3}^{-}$into glial cells. The increased influx of $\mathrm{HCO}_{3}^{-}$produces a cell alkalinization and may acidify extracellular space.

The present study was undertaken to provide a direct test of whether glial cells, when stimulated by an increase in $\left[\mathrm{K}^{+}\right]_{o}$, generate transmembrane acid/base fluxes and acidify extracellular space. Freshly dissociated Müller cells, the principal glial cells of the vertebrate retina, were used to determine the effect of glia on $\mathrm{pH}_{\mathrm{o}}$ in the absence of neurons. Both intracellular and extracellular $\mathrm{pH}$ was monitored as $\left[\mathrm{K}^{+}\right]_{\mathrm{o}}$ was increased. Intracellular $\mathrm{pH}$ $\left(\mathrm{pH}_{\mathrm{i}}\right)$ was measured using standard BCECF ratio imaging techniques, whereas $\mathrm{pH}_{\mathrm{o}}$ was monitored using a novel method in which $\mathrm{BCECF}$ was fixed to coverslips beneath cells. The results confirm that glial cells do indeed acidify extracellular space when stimulated by elevated $\left[\mathrm{K}^{+}\right]_{\text {. }}$.

\section{MATERIALS AND METHODS}

Cell dissociation. Müller cells of the tiger salamander (Ambystoma tigrinum, aquatic stage) were used. Animals were killed by decapitation and pithing. Cells were dissociated as described previously (Newman, 1985). 
Briefly, isolated retinae were incubated in $\mathrm{Ca}^{2+}-\mathrm{Mg}^{2+}$-free Ringer's containing papain $(20 \mathrm{U} / 3 \mathrm{ml})$ and cysteine $(2 \mathrm{mM})$. The tissue was rinsed and maintained on ice in $\mathrm{HCO}_{3}^{-}$Ringer's containing $1 \%$ bovine serum albumin and $0.1 \%$ DNase for a period of 3-8 hr. Cells were isolated by triturating the lissue with a series of Pasteur pipettes with progressively smaller tip openings. Dissociated cells were placed in a perfusion chamber and settled onto a glass coverslip coated with either concanavalin $A$ (Con A) or dextran-BCECF and Con A (see below). The chamber was perfused with a gravity-fed system having an exchange time of $\sim 13 \mathrm{sec}$ (80\% replacement; Newman, 1994). Gas-impermeant Saran tubing was used throughout.

$\mathrm{pH}$ imaging. $\mathrm{pH}$ was measured by excitation ratio imaging of the $\mathrm{pH}$-sensitive fluorescent dye BCECF, as described previously (Newman, 1994). BCECF was excited at two wavelengths, and the ratio of the fluorescence emission was computed using the image processing program Image-1 (Universal Imaging, West Chester, PA). Background images were subtracted before computing ratio images. Dissociated cells were imaged using an inverted microscope with a $40 \times, 0.95$ NA objective and an intensified CCD camera (KS-1381, Videoscope International, Washington, DC).

Intracellular $\mathrm{pH}$. For measurements of $\mathrm{pH}_{\mathrm{i}}$, dissociated Müller cells were filled with BCECF using the membrane-permeant form of the dye, BCECF-AM. Dissociated cells were incubated in $16 \mu \mathrm{M}$ BCECF-AM in $\mathrm{HCO}_{3}^{-}$Ringer's for $16 \mathrm{~min}$ at $0^{\circ} \mathrm{C}$ and then rinsed in $\mathrm{HCO}_{3}^{-}$Ringer's. The dye was excited at $490 \mathrm{~nm}$ and at $440 \mathrm{~nm}$ (the isosbestic excitation wavelength), and fluorescence emission was monitored at $535 \mathrm{~nm}$ (filter set XF16, Omega Optical, Brattleboro, VT). After completion of an experiment, $\mathrm{pH}_{\mathrm{i}}$ for each cell was calibrated by perfusing with a high $\mathrm{K}^{+}$-nigericin solution at $\mathrm{pH} 7.0$. Emission ratios $(490 \mathrm{~nm}$ excitation divided by $440 \mathrm{~nm}$ excitation) were converted to $\mathrm{pH}$ values using this single-point calibration and a modified Michaelis-Menten calibration equation described previously (Newman, 1994),

$$
\frac{I_{490}}{I_{440}}=1+b \times\left(\frac{10^{(\mathrm{pH}-p K)}}{1+10^{(\mathrm{pH}-p K)}}-\frac{10^{(7.0-p K)}}{1+10^{(7.0-p K)}}\right),
$$

where $I_{490} / I_{440}$ represents the fluorescence emission ratio, normalized to the ratio at $\mathrm{pH} 7.0$. The two parameters in Equation 1 describing the $\mathrm{pH}$ sensitivity of $\mathrm{BCECF}, p K$ and $b$, equal 7.25 and 1.82 , respectively, as determined previously (Newman, 1994).

Extracellular $\mathrm{pH}$. A variant of the standard ratio imaging technique was developed to measure $\mathrm{pH}_{\mathrm{o}}$ immediately outside of dissociated cells. The coverslips under the isolated cells were coated with a thin layer of BCECF before use. Ratio imaging of this extracellular BCECF yielded a measure of $\mathrm{pH}$, both of the bath solution and of the solution in the narrow space between the dissociated cells and the underlying coverslip.

Coverslips were coated with BCECF using the following protocol. Coverslips were cleaned in $100 \%$ ethanol, rinsed in $\mathrm{H}_{2} \mathrm{O}$, coated with gelatin ( $1 \%$ aqueous solution), and air-dried. A $1 \%$ solution of dextranconjugated BCECF $(70,000 \mathrm{MW})$ in HEPES Ringer's was then applied to the coverslips, with $2 \mu \mathrm{l}$ of the solution covering an area of $0.4 \mathrm{~cm}^{2}$ added to each coverslip. The coverslips were air-dried and fixed overnight in formaldehyde fumes at $36^{\circ} \mathrm{C}$, postfixed in $4 \%$ formaldehyde for $30 \mathrm{~min}$, rinsed five times in $\mathrm{H}_{2} \mathrm{O}$, and air-dried. A Con A solution was applied to the coverslips over the dextran-BCECF $\left(100 \mu \mathrm{l}\right.$ of $0.15 \%$ Con $\mathrm{A}$ in $\mathrm{H}_{2} \mathrm{O}$, covering $\sim 1.3 \mathrm{~cm}^{2}$ per coverslip) and air-dried.

The fluorescence properties of dextran-BCECF fixed with formaldehyde were characterized with fluorescence spectroscopy. Excitation spectra (Fig. 1.1) show that an excitation wavelength of $508 \mathrm{~nm}$ produces maximal emission, whereas the isosbestic wavelength is $465 \mathrm{~nm}$ (for $\mathrm{pH}$ values 6.6-8.2). Emission for the dye peaks at $536 \mathrm{~nm}$ (Fig. $1 B$ ) $\mathrm{pH}_{\mathrm{o}}$ measurements using dextran-BCECF were made with excitation filters $465 \mathrm{~nm}$ ( $20 \mathrm{~nm}$ bandpass) and $508 \mathrm{~nm}$ (10 nm bandpass), and emission was monitored at $535 \mathrm{~nm}$ ( $25 \mathrm{~nm}$ bandpass). Emission ratios were calculated ( $508 \mathrm{~nm}$ excitation divided by $465 \mathrm{~nm}$ excitation) after subtraction of background images. Changes in $\mathrm{pH}_{\mathrm{o}}$ were small $(0.01-0.05 \mathrm{pH}$ units), and signals were averaged for $5-15 \mathrm{sec}$ to reduce noise. This limited the temporal resolution of $\mathrm{pH}_{\mathrm{o}}$ measurements to $\sim 10 \mathrm{sec}$.

The $\mathrm{pH}$ sensitivity of formaldehyde-fixed dextran-BCECF was determined in calibration experiments. Coverslips were perfused in a series of HEPES Ringer's with $\mathrm{pH}$ values ranging from 6.2 to 8.2. As the $\mathrm{pH}$ increased, the BCECF emission ratio rose in a sigmoidal fashion, in a manner similar to that observed for $\mathrm{pH}_{\mathrm{i}}$ measurements. Calibration curves were fit with a modified Equation 1, with ratio values normalized
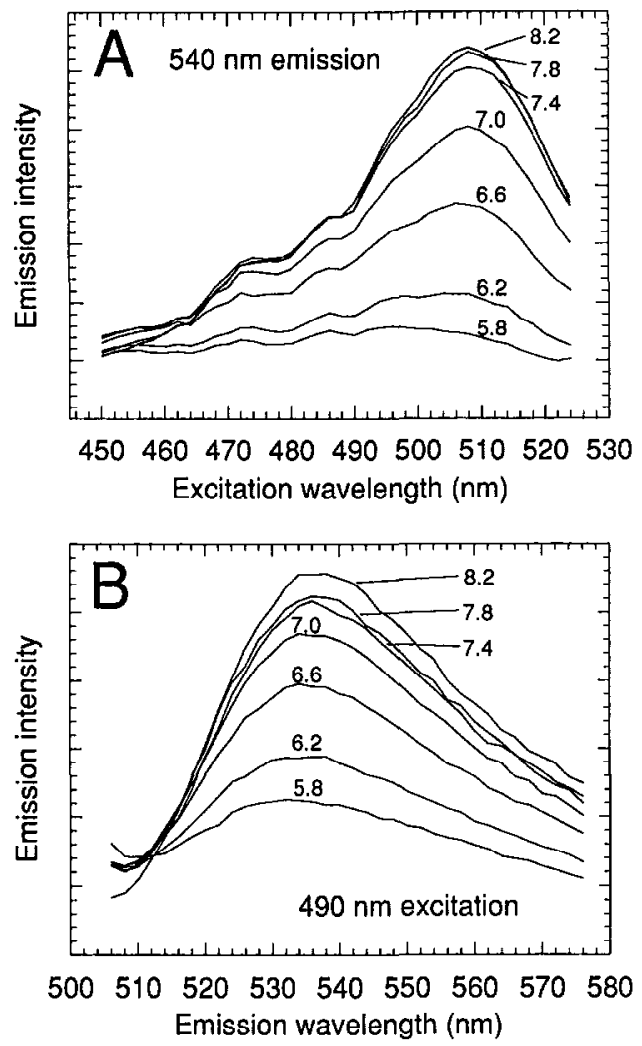

Figure 1. Excitation and emission spectra of dextran-BCECF fixed to coverslips with formaldehyde. BCECF-coated coverslips were bathed in HEPES Ringer's with $\mathrm{pH}$ values indicated. $A$, Excitation spectra. Fluorescence emission measured at $540 \mathrm{~nm}$. Peak emission occurs for an excitation wavelength of $508 \mathrm{~nm}$. For $\mathrm{pH}$ values $6.6-8.2$, the isosbestic wavelength is $465 \mathrm{~nm}$. $B$, Emission spectra. BCECF excited at $490 \mathrm{~nm}$. Peak emission occurs at $536 \mathrm{~nm}$.

to $\mathrm{pH} 7.4$ instead of 7.0. Mean values for equation parameters $p K$ and $b$ were equal to $6.87 \pm 0.08$ and $0.712 \pm 0.019(n=8)$, respectively.

In addition to using standard ratio imaging techniques to measurc $\mathrm{pH}_{0}$, $\mathrm{pH}$ changes were determined by calculating "difference ratio images." Fluorescence images of BCECF bound to coverslips were obtained using $508 \mathrm{~nm}$ excitation (the $\mathrm{pH}$-sensitive wavelength), averaging 256 consecutive frames. Images were obtained during a test period and during control periods before and after the test period. After background subtraction, a difference ratio image was calculated by dividing the average of the two control images by the test image. Changes in BCECF fluorescence, which reflect shifts in $\mathrm{pH}_{\mathrm{o}}$, were typically $<1 \%$, and low pass spatial averaging was used to reduce noise. Images were calibrated by converting percentage change in fluorescence to $\mathrm{pH}_{\mathrm{o}}$ changes using the calibration equation described above and assuming an initial $\mathrm{pH}_{\mathrm{o}}$ of 7.4. Averaged images were acquired with 16-bit resolution, and difference ratio images were computed using Metamorph software (Universal Imaging).

Solutions. $\mathrm{HCO}_{3}^{-}$-buffered Ringer's contained (in mM): $\mathrm{NaCl} 80.0, \mathrm{KCl}$ 2.5, $\mathrm{CaCl}_{2} 1.8, \mathrm{MgCl}_{2} 0.8$, dextrose 10.0 , and $\mathrm{NaHCO}_{3} 26$. It was equilibrated with $5 \% \mathrm{CO}_{2}$ in $\mathrm{O}_{2}$ and had a $\mathrm{pH}$ of $\sim 7.4$ at room temperature. HEPES-buffered Ringer's contained (in mM): $\mathrm{NaCl} 98.5, \mathrm{KCl} 2.5, \mathrm{CaCl}_{2}$ $1.8, \mathrm{MgCl}_{2} 0.8$, dextrose 10.0 , and HEPES 10.0. It was adjusted to $\mathrm{pH} 7.4$ with $\mathrm{NaOH}$ and equilibrated with $100 \% \mathrm{O}_{2}$. In high $\mathrm{K}^{+}$solutions, $\mathrm{KCl}$ was substituted for $\mathrm{NaCl}$. In zero $\mathrm{Na}^{+}$solutions, $N$-methyl-D-glucamine chloride was substituted for $\mathrm{NaCl}$, and choline bicarbonate for $\mathrm{NaHCO}_{3}$. In zero $\mathrm{Cl}^{-}$solutions, methane sulfonate was substituted for $\mathrm{Cl}^{-}$. The high $\mathrm{K}^{+}$-nigericin calibration solution contained $N$-methyl-D-glucamine, $18.5 \mathrm{~mm} ; \mathrm{KCl}, 72.5 \mathrm{~mm} ; \mathrm{CaCl}_{2}, 1.8 \mathrm{~mm} \mathrm{MgCl}_{2}, 0.8 \mathrm{~mm}$; dextrose, 10.0 $\mathrm{mM}$; HEPES, $20.0 \mathrm{mM}$; and nigericin, $10 \mu \mathrm{M}$.

Dextran-BCECF (70,000 MW), BCECF-AM, and nigericin were obtained from Molccular Probes (Eugene, OR); amiloride, bumetanide, and methazolamide were obtained from Sigma (St. Louis, MO). Benzo- 
lamide was the generous gift of Thomas Maren and Curtis Conroy. Results are given as mean \pm SD $(n)$.

\section{RESULTS}

\section{Resting intracellular pH}

The resting $\mathrm{pH}_{\mathrm{i}}$ of dissociatcd Müller cells was determined in $\mathrm{HCO}_{3}^{-}$and HEPES Ringer's. In $\mathrm{HCO}_{3}^{-}$-buffered Ringer's, $\mathrm{pH}_{\mathrm{i}}$ equaled $7.08 \pm 0.04$ (27), whereas in HEPES, $\mathrm{pH}_{\mathrm{i}}$ equaled $6.96 \pm$ $0.06(44)$. When the bathing solution was switched from $\mathrm{HCO}_{3}^{-}$to HEPES, $\mathrm{pH}_{\mathrm{i}}$, responding to a decrease in $\mathrm{PCO}_{2}$, transiently shifted to a more alkaline value before gradually acidifying over a 20-35 min period. The shift to a more acidic resting $\mathrm{pH}_{\mathrm{i}}$ indicates that one or more $\mathrm{HCO}_{3}^{-}$transport systems contribute to $\mathrm{pH}_{\mathrm{i}}$ regulation in Müller cells.

There was little change in $\mathrm{pH}_{\mathrm{i}}$ when $\mathrm{Cl}^{-}$was removed from the bathing solution, suggesting that $\mathrm{Cl}^{-}$-dependent transporters are not involved in maintaining steady state $\mathrm{pH}_{\mathrm{i}}$. In $\mathrm{HCO}_{3}^{-}$-buffered solution, removal of $\mathrm{Cl}^{-}$reduced $\mathrm{pH}_{\mathrm{i}}$ by only $0.03 \mathrm{pH}$ units, to $7.05 \pm 0.03(10)$. In HEPES-buffered solution, $\mathrm{pH}_{\mathrm{i}}$, in the absence of $\mathrm{Cl}^{-}$, was $6.96 \pm 0.04(8)$, identical to the value measured with $\mathrm{Cl}^{-}$present.

\section{$\mathbf{K}^{+}$-induced intracellular alkalinization}

Many glial cells (Astion and Orkand, 1988; Kettenmann and Schlue, 1988; O'Connor et al., 1994), including Müller cells (Newman, 1991), possess a $\mathrm{Na}^{+} / \mathrm{HCO}_{3}^{-}$cotransport system. The cotransporter is electrogenic, transporting one $\mathrm{Na}^{+}$along with two or three $\mathrm{HCO}_{3}^{-}$. Depending on the precise stoichiometry, which varies in different preparations (Soleimani et al., 1987; Deitmer and Schlue, 1989; Hughes et al., 1989; Newman, 1991; O'Connor et al., 1994), the reversal potential of the cotransporter is somewhat positive or negative of the cell membrane potential. When the cell resting potential is positive to the cotransporter reversal potential, $\mathrm{Na}^{\prime}$ and $\mathrm{HCO}_{3}$ are tonically transported into the cell. When the cell is depolarized, this $\mathrm{Na}^{+}$and $\mathrm{HCO}_{3}^{-}$influx is increased.

Cotransporter activity can be assessed by monitoring $\mathrm{pH}_{\mathrm{i}}$ as $\left[\mathrm{K}^{+}\right]_{\mathrm{o}}$ is varied. Raising $\left[\mathrm{K}^{+}\right]_{\mathrm{o}}$ depolarizes cells and should lead to an intracellular alkalinization, generated by the increased influx of $\mathrm{HCO}_{3}^{-}$through the cotransporter.

In the current study, increasing $\left[\mathrm{K}^{+}\right]_{\mathrm{o}}$ did indeed produce an intracellular alkalinization in Müller cells (Fig. 2). In response to a step increase in $\left[\mathrm{K}^{+}\right]_{o}$, intracellular alkalinization proceeded at a near constant rate for several minutes, slowing down and eventually reaching plateau after $10 \mathrm{~min}$ or more. When $\left[\mathrm{K}^{+}\right]_{\mathrm{o}}$ was subsequently reduced to the control level of $2.5 \mathrm{mM}, \mathrm{pH}_{\mathrm{i}}$ recovered to near baseline $\mathrm{pH}_{\mathrm{i}}$. The initial rate of alkalinization, rather than the final, plateau value of $\mathrm{pH}_{\mathrm{i}}$, was measured to quantify the response, as it gives a more accurate measure of $\mathrm{Na}^{+} / \mathrm{HCO}_{3}^{-}$ cotransport activity.

In some cells, the $\mathrm{K}^{+}$-evoked alkalinization proceeded in two phases: an initial, rapid alkalinization lasting 10-20 sec, followed by a slower alkalinization continuing for several minutes. The initial rapid phase of alkalinization was quite distinct in some cells (arrows in Figs. $2 B$ and 4 ); its origin is not known. It is probably not caused by $\mathrm{K}^{+}$-induced cell swelling, however, which would lead to a $\left[\mathrm{HCO}_{3}^{-}\right]_{\mathrm{i}}$ decrease and to an intracellular acidification.

The rate of $\mathrm{K}^{+}$-induced intracellular alkalinization was quantified by fitting a tangent line by eye to $\mathrm{pH}_{\mathrm{i}}$ records. The initial, rapid phase of alkalinization was disregarded when making these measurements. The $\mathrm{K}^{+}$-induced alkalinization rate was equal to $0.047 \pm 0.013(39) \mathrm{pH}$ units $/ \mathrm{min}$ when $\left[\mathrm{K}^{+}\right]_{\mathrm{o}}$ was increased from
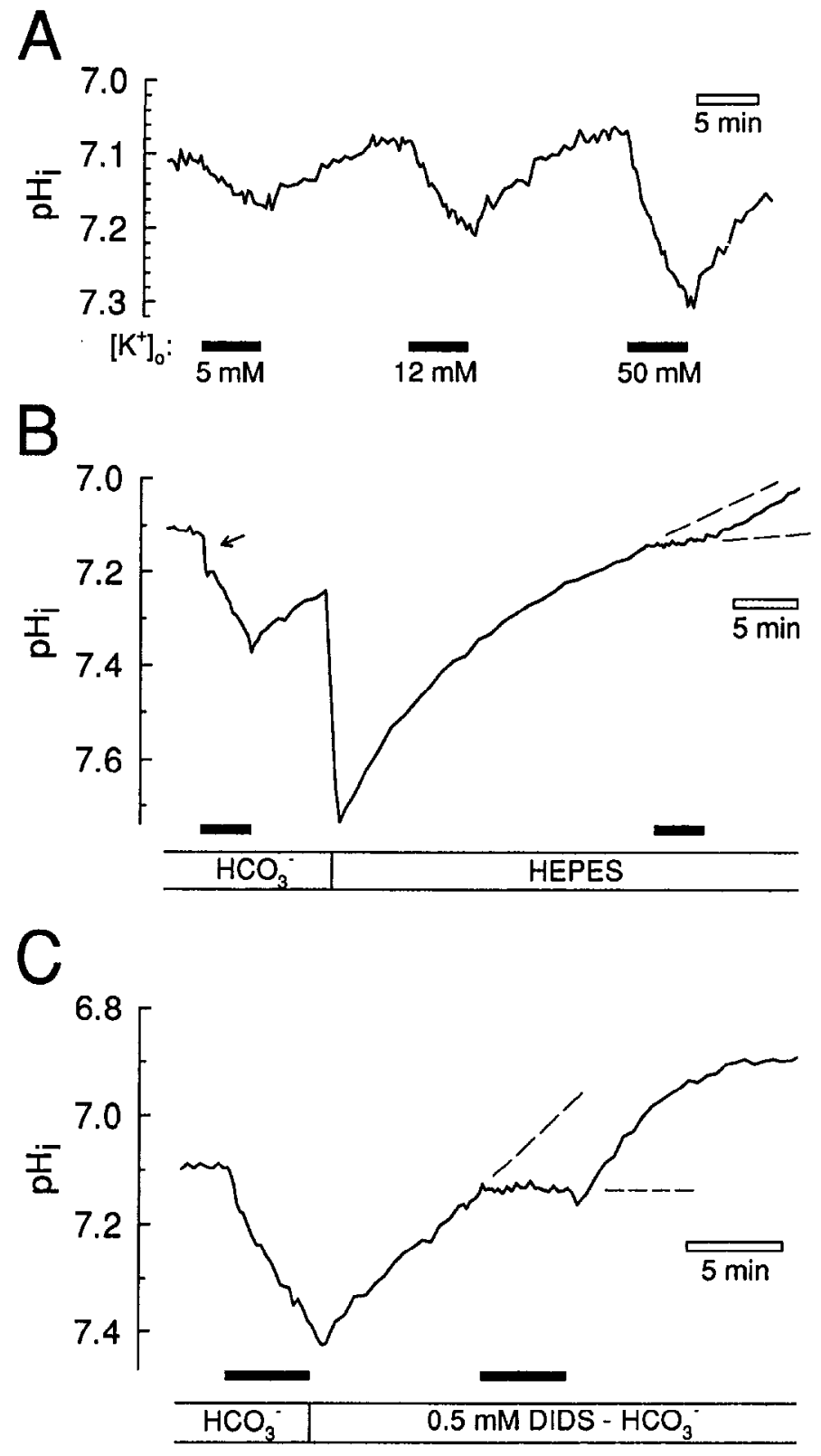

Figure 2. Potassium-evoked intracellular alkalinization in salamander Müller cells. $A$, The rate and extent of alkalinization is greater for larger increases in $\left[\mathrm{K}^{+}\right]_{\mathrm{u}}$. Application of high $\left[\mathrm{K}^{+}\right]_{\mathrm{u}}$ solutions are indicated by filled bars. Note that acidification (an increase in $\left[\mathrm{H}^{+}\right]$) is indicated as an upward deflection in this and subsequent $\mathrm{pH}$ plots. $B$, Substitution of IIEPES for $\mathrm{ICOO}_{3}^{-}$reduces the rate of $\mathrm{K}^{+}$-evoked intracellular alkalinization. HEPES substitution generates a transient alkalinization followed by a slow acidification and results in the reduction of the $\mathrm{K}^{\prime}$-evoked alkalinization, in this example, to $50 \%$ of control. The alkalinization rate in HEPES is measured as the difference between the slope of the plot during high $\mathrm{K}^{+}$application and the slope just before application (indicated by dashed lines). In this and the following figures, application of $50 \mathrm{~mm}$ $\left[\mathrm{K}^{+}\right]_{\mathrm{o}}$ solutions is indicated by filled bars below the plots. Arrow indicates initial rapid phase of $\mathrm{K}^{+}$-evoked alkalinization (see text). $C$, Addition of $0.5 \mathrm{~mm}$ DIDS, a $\mathrm{Na}^{+} / \mathrm{HCO}_{3}^{-}$cotransport blocker, reduces the rate of $\mathrm{K}^{+}$-evoked alkalinization, in this example, to $43 \%$ of control. Note that DIDS addition results in an acidification of the resting $\mathrm{pH}_{4}$.

2.5 to $50 \mathrm{~mm}$. (The average rate of $\mathrm{K}^{+}$-induced alkalinization varied somewhat in different groups of animals and times of year. The reason for this variation is not known.)

The relation between the rate of alkalinization and the magnitude of the $\left[\mathrm{K}^{+}\right]_{\mathrm{o}}$ increase was determined in individual cells by 
exposing them sequentially to 5,12 , and $50 \mathrm{~mm}\left[\mathrm{~K}^{+}\right]_{\mathrm{o}}$ (Fig. $2 A$ ). Mean alkalinization rates were $0.008 \pm 0.004,0.017 \pm 0.005$, and $0.035 \pm 0.011(8) \mathrm{pH}$ units/min, respectively, for the three $\left[\mathrm{K}^{+}\right]_{\mathrm{o}}$ levels.

\section{$\mathrm{Na}^{+} / \mathrm{HCO}_{3}^{-}$cotransport}

The $\mathrm{K}^{+}$-induced alkalinization described above could be generated by the voltage-dependent $\mathrm{Na}^{+} / \mathrm{HCO}_{3}^{-}$cotransport system of Müller cells. If this cotransporter were solely responsible for the alkalinization, the $\mathrm{K}^{+}$-induced $\mathrm{pH}$ shift would be abolished by removal of $\mathrm{IICO}_{3}^{-}$from the bathing solution and by addition of cotransporter blockers. This proved to be only partially true.

Cell alkalinization evoked by raising $\left[\mathrm{K}^{+}\right]_{\circ}$ was reduced, hut not eliminated, when the bath solution was switched from $\mathrm{HCO}_{3}^{-}$buffered to HEPES-buffered Ringer's (Fig. $2 B$ ). To obtain an accurate comparison of the $\mathrm{K}^{+}$-induced alkalinizations in $\mathrm{HCO}_{3}^{-}$ and HEPES Ringer's, the two responses were measured at the same $\mathrm{pH}_{\mathrm{i}}$. This avoided the potential complication of the $\mathrm{HCO}_{3}^{-}$independent component of the alkalinization being $\mathrm{pH}$-dependent. Replacement of $\mathrm{HCO}_{3}^{-}$with HEPES resulted in an initial alkalinization followed by a slow acidification (Fig. $2 B$ ), which eventually reached plateau at a $\mathrm{pH}$ more acidic than the resting $\mathrm{pH}$ in $\mathrm{HCO}_{3}^{-}$. The $\mathrm{K}^{+}$-evoked alkalinization in HEPES was measured at the time when the acidifying $\mathrm{pH}_{\mathrm{i}}$ crossed the control $\mathrm{pH}_{\mathrm{i}}$ level. Typically, $\mathrm{K}^{+}$application did not produce an actual alkalinization, but rather produced a reduction in the rate of acidification. The rate of $\mathrm{K}^{+}$-evoked "alkalinization" in HEPES was calculated as the difference in the $\mathrm{pH}_{\mathrm{i}}$ slope at times just before and during $\mathrm{K}^{+}$application (Fig. $2 B$, dashed lines).

Cell alkalinization evoked by raising $\left[\mathrm{K}^{+}\right]_{\mathrm{o}}$ from 2.5 to $50 \mathrm{~mm}$ was reduced from $0.046 \pm 0.008$ to $0.019 \pm 0.008$ (16) $\mathrm{pH}$ units/min when the bath solution was switched from $\mathrm{HCO}_{3}^{-}-$ buffered to HEPES-buffered Ringer's, a reduction to $42 \%$ of the control response. Intracellular buffering power is substantially lower for cells bathed in HEPES Ringer's compared with cells in $\mathrm{HCO}_{3}^{-}$Ringer's (Chesler, 1990). Thus, the $\mathrm{HCO}_{3}^{-}$-independent component of the alkalinization observed in HEPES is larger than it would be if the $\mathrm{CO}_{2} / \mathrm{HCO}_{3}^{-}$buffering system were present.

Addition of the cotransport inhibitor 4,4'-diisothiocyanato-stilbene-2,2'-disulfonic acid (DIDS; Boron and Boulpaep, 1989) had an effect on the $\mathrm{K}^{+}$-induced alkalinization similar to that of $\mathrm{HCO}_{3}^{-}$removal. Raising $\left[\mathrm{K}^{+}\right]_{\mathrm{o}}$ to $50 \mathrm{~mm}$ produced an alkalinization that was reduced from $0.045 \pm 0.009$ to $0.017 \pm 0.007$ (12) $\mathrm{pH}$ units/min on addition of $0.5 \mathrm{~mm}$ DIDS, a reduction to $36 \%$ of the control response (Fig. 2C). As in the HEPES-substitution experiment, the $\mathrm{K}^{+}$-induced alkalinization in DIDS was measured at the time when the acidifying $\mathrm{pH}_{\mathrm{i}}$ equaled the control baseline.

Steady-state $\mathrm{pH}_{\mathrm{i}}$ shifted from $7.11 \pm 0.01$ to $6.86 \pm 0.14$ (9) on addition of DIDS. This DIDS-evoked acidification provides additional support for the supposition that $\mathrm{HCO}_{3}^{-}$-dependent transport systems play a role in establishing resting $\mathrm{pH}_{i}$.

If the $\mathrm{K}^{+}$-evoked alkalinization is generated by the $\mathrm{Na}^{+} / \mathrm{HCO}_{3}^{-}$ cotransporter, in addition to being $\mathrm{HCO}_{3}^{-}$-dependent and DIDSsensitive, it also should be $\mathrm{Na}^{+}$-dependent. When $\mathrm{Na}^{+}$was removed from the $\mathrm{HCO}_{3}^{-}$bath, $\mathrm{pH}_{\mathrm{i}}$ acidified steadily and relatively rapidly (Fig. $3 A$ ). The rate of acidification was equal to $0.079 \pm$ 0.014 (7) $\mathrm{pH}$ units/min. The speed of the acidification made it impractical to measure the $\mathrm{Na}^{+}$-dependency of the $\mathrm{K}^{+}$-induced alkalinization at control $\mathrm{pH}_{\mathrm{i}}$ lcvels, and its dependency on $\mathrm{Na}^{+}$ was not determined. The acidification evoked by $\mathrm{Na}^{+}$removal is consistent, however, with the presence of a $\mathrm{Na}^{+} / \mathrm{HCO}_{3}^{-}$cotransporter in Müller cells.
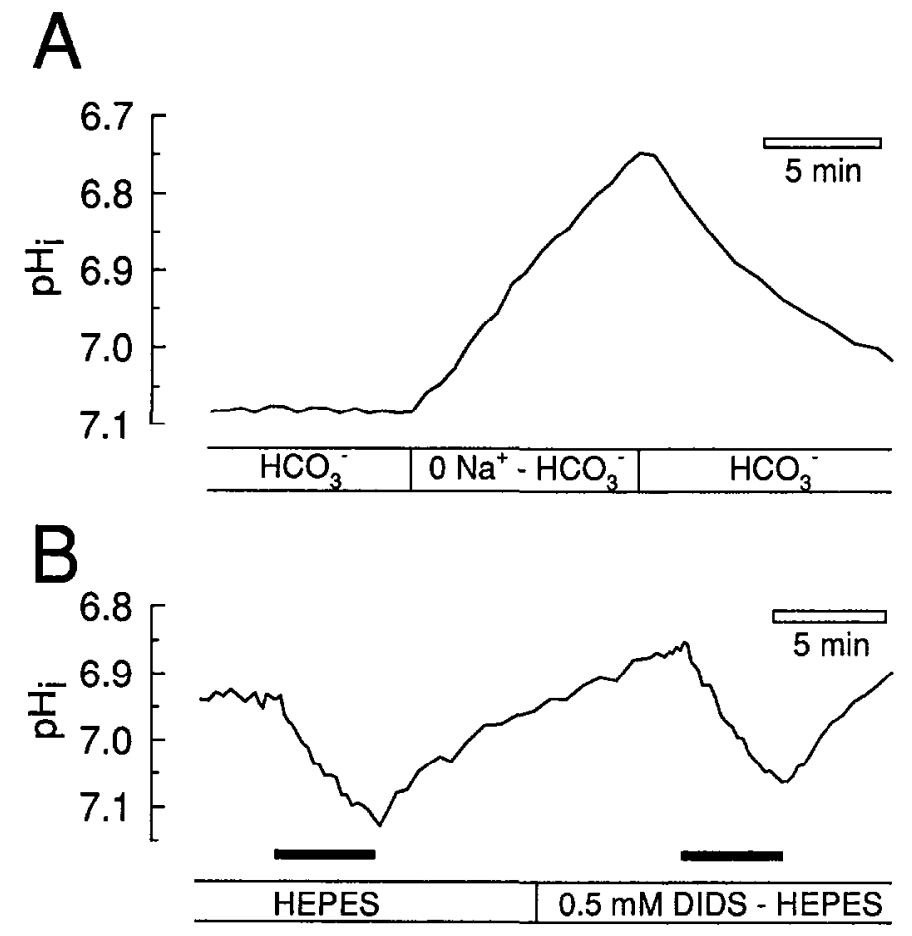

Figure 3. $A$, Removal of $\mathrm{Na}^{+}$results in a rapid intracellular acidification. $N$-methyl-D-glucamine and choline are substituted for $\mathrm{Na}^{+}$in the $\mathrm{HCO}_{3}^{-}$ solution. $B$, DIDS has no effect on the $\mathrm{HCO}_{3}^{-}$-independent component of intracellular alkalinization. The rate of $\mathrm{K}^{+}$-evoked alkalinization in HEPES Ringer's is not substantially altered by the addition of $0.5 \mathrm{~mm}$ DIDS.

The observation that $\mathrm{HCO}_{3}^{-}$removal and DIDS addition reduce the $\mathrm{K}^{+}$-evoked alkalinization to 42 and $36 \%$, respectively, of the control responses supports the conjecture that a large fraction (but not all) of the alkalinization is generated by modulation of a $\mathrm{Na}^{+} / \mathrm{HCO}_{3}^{-}$cotransport system. The nature of the $\mathrm{HCO}_{3}^{-}$-independent component of the $\mathrm{K}^{+}$-evoked alkalinization remains unclear.

It is possible that a $\mathrm{Cl}^{-}$-dependent transporter contributes to the $\mathrm{K}^{+}$-evoked alkalinization. This proved not to be the case. Dissociated cells were bathed in $\mathrm{Cl}^{-}$-free Ringer's for periods ranging from 37 to $65 \mathrm{~min}$ before testing for depolarizationinduced alkalinization. In the absence of $\mathrm{Cl}^{-}$, the rate of alkalinization evoked by raising $\left[\mathrm{K}^{+}\right]_{0}$ to $50 \mathrm{~mm}$ equaled $0.047 \pm 0.009$ (10) $\mathrm{pH}$ units/min, a rate identical to that with $\mathrm{Cl}^{-}$present.

Similarly, the alkalinization was not substantially diminishcd by blockers of other transport systems. In the presence of $2 \mathrm{~mm}$ amiloride, a blocker of $\mathrm{Na}^{+} / \mathrm{H}^{+}$exchange, the rate of alkalinization was $81.9 \pm 7.2 \%$ (5) of control. With the addition of $20 \mu \mathrm{M}$ bumetanide, a blocker of $\mathrm{Na}^{+} / \mathrm{K}^{+} / 2 \mathrm{Cl}^{-}$cotransport, the rate of alkalinization was $86.5 \pm 6.3 \%$ (3) of control.

\section{$\mathrm{HCO}_{3}^{-}$-independent intracellular alkalinization}

If the alkalinization that occurs in the absence of $\mathrm{HCO}_{3}^{-}$is truly independent of the $\mathrm{Na}^{+} / \mathrm{HCO}_{3}^{-}$cotransport system, this component of the $\mathrm{K}^{+}$-evoked response should not be blocked by DIDS. This proved to be the case (Fig. $3 B$ ). The rate of $\mathrm{K}^{+}$-evoked alkalinization in a group of cells bathed in HEPES solution was $0.022 \pm 0.009(17) \mathrm{pH}$ units/min and was essentially unchanged (101 $\pm 22 \%$ of control) after addition of 0.5 mм DIDS. 


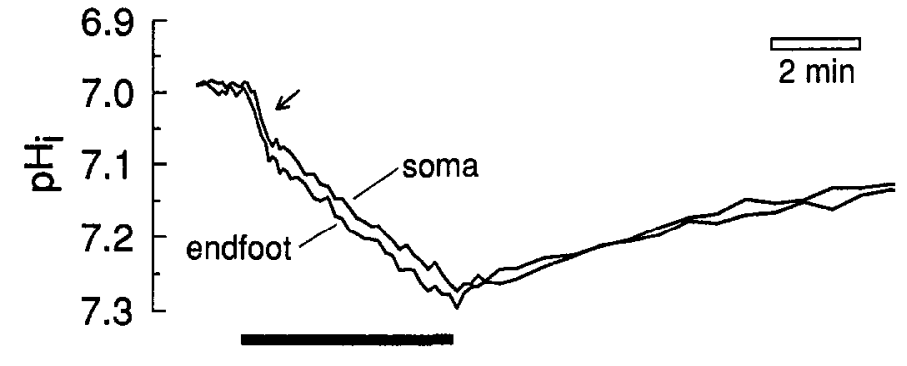

Figure 4. The rate of $\mathrm{K}^{+}$-evoked alkalinization is identical in all cell regions. The intracellular alkalinization is recorded simultaneously from the endfoot and soma of a single cell. The rate of alkalinization is the same in both cell regions. The slight offset in the two $\mathrm{pH}_{\mathrm{i}}$ records is because of a larger initial rapid phase of the alkalinization (indicated by arrow) in the endfoot record.

\section{Carbonic anhydrase}

Müller cells have high levels of intracellular carbonic anhydrase (CA). If a large fraction of the $\mathrm{K}^{+}$-evoked alkalinization is generated by a transmembrane $\mathrm{HCO}_{3}^{-}$flux, CA might be expected to influence the alkalinization. This was tested by determining the effect of methazolamide, which inhibits CA in Müller cells (Newman, 1994), on the rate of $\mathrm{K}^{+}$-evoked alkalinization.

The $\mathrm{K}^{+}$-induced response was unchanged on addition of $10^{-4} \mathrm{M}$ methazolamide. The rate of alkalinization in a group of cells bathed in $\mathrm{HCO}_{3}^{-}$solution was $0.036 \pm 0.010$ (12) $\mathrm{pH}$ units/ min and was nearly identical ( $99 \pm 23 \%$ of control) on addition of the CA inhibitor.

The absence of an effect of CA on the alkalinization suggests that the transmembrane $\mathrm{HCO}_{3}^{-}$fluxes generated by the cotransporter are sufficiently slow so that the reaction $\mathrm{HCO}_{3}^{-}+\mathrm{H}^{+} \rightarrow$ $\mathrm{CO}_{2}+\mathrm{H}_{2} \mathrm{O}$ (required to produce cell alkalinization) proceeds fast enough, even in the absence of CA. This is most likely the case, as changes in Müller cell $\mathrm{pH}_{\mathrm{i}}$, evoked by increases in $\mathrm{P}_{\mathrm{CO}_{2}}$, can occur at a rate of $0.36 \mathrm{pH}$ units/min in the absence of $\mathrm{CA}$ (Newman, 1994). Similar results have been observed in leech glial cells (Rose and Deitmer, 1995a) in which the addition of a CA inhibitor has no effect on stimulus-evoked cell alkalinization.

\section{Localization of $\mathrm{Na}^{+} / \mathrm{HCO}_{3}^{-}$cotransport with $\mathrm{pH}_{1}$ measurements}

Results from previous electrophysiological studies of $\mathrm{Na}^{+} / \mathrm{HCO}_{3}^{-}$ cotransport in Müller cells have demonstrated that cotransporter sites are localized preferentially to the cell endfoot (Newman and Astion, 1991; Newman, 1991). This finding implies that transmembrane $\mathrm{HCO}_{3}^{-}$fluxes are largest at the endfoot and suggests that $\mathrm{K}^{+}$-evoked intracellular alkalinization might be larger at the endfoot than in other cell regions. This prediction was tested by measuring the rates of $\mathrm{K}^{+}$-evoked alkalinization in control cells and in cells that had lost their endfeet during the isolation procedure.

In a group of cells that lacked their endfeet and a large portion of their proximal processes, the rate of alkalinization evoked by increasing $\left[\mathrm{K}^{+}\right]_{\mathrm{o}}$ to $50 \mathrm{~mm}$ was equal to $0.030 \pm 0.10(15) \mathrm{pH}$ units/min. In control cells from the same preparations, the alkalinization rate was $0.060 \pm 0.019(9)$. This finding, that cells with their endfeet intact have twice the alkalinization rate as cells without endfeet, is consistent with the presence of a greater density of $\mathrm{Na}^{+} / \mathrm{HCO}_{3}^{-}$cotransport sites at the cndfoot.

Localization of cotransporter sites to the endfoot also was tested by simultaneously measuring $\mathrm{K}^{+}$-induced alkalinization in the soma and endfoot regions of individual cells. If $\mathrm{HCO}_{3}^{-}$flux is greater at the endfoot, this cell region may show a greater alkalinization rate than other regions.

This proved not to be the case. In all cells tested $(n=44)$, the alkalinization rate measured in the endfoot was nearly identical to the rate in the soma (Fig. 4). This result could be taken as evidence that cotransporter sites are not localized preferentially to the endfoot. Alternatively, $\mathrm{K}^{+}$-evoked $\mathrm{HCO}_{3}^{-}$fluxes could still be greater at the endfoot, but the rate of intracellular alkalinization too slow to establish a $\mathrm{pH}$ gradient within the cell. The rate at which acid/base equivalents diffuse within cells might be sufficiently rapid to prevent a measurable buildup of $\mathrm{HCO}_{3}^{-}$at the endfoot. This seems likely, as $\mathrm{HCO}_{3}^{-}$will diffuse from the endfoot to the soma, a distance of $\sim 60 \mu \mathrm{m}$, in $\sim 4.8 \mathrm{sec}$ (calculated from the mean square diffusion distance and an effective diffusion coefficient, corrected for tortuosity (Nicholson and Phillips, 1981), of $\left.3.75 \times 10^{-6} \mathrm{~cm}^{2} \times \mathrm{sec}^{-1}\right)$. This diffusion time is much shorter than the time it takes for $\mathrm{K}^{+}$-induced alkalinization to develop.

\section{Measurement of extracellular $\mathrm{pH}$}

The findings described above leave several questions unanswered, including the following: (1) does activation of the $\mathrm{Na}^{+} / \mathrm{HCO}_{3}^{-}$ cotransporter lead to shifts in $\mathrm{pH}_{n},(2)$ is the $\mathrm{HCO}_{3}^{-}$-independent component of intracellular alkalinization generated by a transmembrane acid/base flux, and (3) are cotransporters localized to the endfeet of Müller cells? These questions can be addressed by monitoring $\mathrm{pH}_{\mathrm{o}}$ in the vicinity of isolated cells.

To measure $\mathrm{pH}_{\mathrm{o}}$, dissociatcd cclls wcre placcd on coverslips previously coated with the $\mathrm{pH}$-indicator dye BCECF. The $\mathrm{pH}$ of the bath solution in the narrow space between cell and coverslip was monitored by ratio imaging of the dye. $\mathrm{The}_{\mathrm{pH}}$ in this narrow space is determined by a balance between cell transmembrane acid/base fluxes and diffusion of acid/base equivalents to the bulk bath solution. This imaging method can complement the widely used $\mathrm{pH}$-sensitive microelectrode technique for measuring $\mathrm{pH}_{\mathrm{o}}$. Although $\mathrm{pH}$ electrodes have lower noise, $\mathrm{pH}_{\mathrm{o}}$ imaging has the benefit of being able to determine $\mathrm{pH}$ values in many regions simultaneously. This is particularly advantageous when determining the localization of acid/base fluxes across the surface of a cell.

\section{$\mathbf{K}^{+}$-induced extracellular acidification}

If the $\mathrm{HCO}_{3}^{-}$-dependent intracellular alkalinization evoked by raising $\left[\mathrm{K}^{+}\right]_{0}$ is generated by modulation of the $\mathrm{Na}^{+} / \mathrm{HCO}_{3}^{-}$ cotransporter, raising $\left[\mathrm{K}^{+}\right]_{o}$ should also gencratc an cxtraccllular acidification. This proved to be the case. Increasing $\left[\mathrm{K}^{+}\right]_{\mathrm{o}}$ from 2.5 to $50 \mathrm{mM}$ evoked an extracellular acidification ranging from 0.01 to $0.05 \mathrm{pH}$ units in amplitude (Fig. $5 B$, "difference" trace). The acidification was fully developed within seconds and reached plateau at a level that remained constant as long as $\left[\mathrm{K}^{+}\right]_{o}$ remained high.

Changes in $\mathrm{pH}_{\mathrm{o}}$ beneath cells reflect variations in bath $\mathrm{pH}$ as well as in cellular acid/base fluxes. This is a potential source of artifact when measuring $\mathrm{pH}_{\mathrm{o}}$, inasmuch as evoked $\mathrm{pH}_{\mathrm{o}}$ changes are small and it is impossible to match the $\mathrm{pH}$ of different bath solutions perfectly. To minimize this source of artifact, $\mathrm{pH}_{\mathrm{o}}$ changes beneath cells were always compared with the $\mathrm{pH}_{\mathrm{o}}$ of the bulk solution. This was accomplished by subtracting $\mathrm{pH}_{\mathrm{o}}$ values from regions of the coverslip in contact with the bulk solution (Fig. 5, bath) from regions lying beneath a cell (Fig. 5, endfoot). The rcsulting difference in $\mathrm{pH}_{\mathrm{o}}$ measurcments (Fig. $5 B$, difference) reflects transmembrane acid/base fluxes but not changes in the $\mathrm{pH}$ of the bath solution. $\mathrm{pH}_{\mathrm{o}}$ measurements described in the experiments below were made using this "difference" correction. 
Figure 5. Measurement of $\mathrm{K}^{+}$-evoked extracellular acidification beneath Müller cells. $A$, Nomarski micrograph of a dissociated Müller cell. Typical regions from which endfoot and bath $\mathrm{pH}_{\mathrm{o}}$ are measured are indicated by black outlines. Scale bar, $20 \mu \mathrm{m}$. B, Records of $\mathrm{pH}_{\mathrm{o}}$ variations evoked by $\left[\mathrm{K}^{+}\right]_{\mathrm{o}}$ increases. The corrected endfoot $\mathrm{pH}_{\mathrm{o}}$ record (difference plot) is obtained by subtracting the bath record from the endfoot record. As indicated by the bath record, the $\mathrm{pH}$ of the $50 \mathrm{~mm}$ $\mathrm{K}^{+}$solution is slightly more alkaline than is the control solution. The endfoot and bath records have been offset vertically.
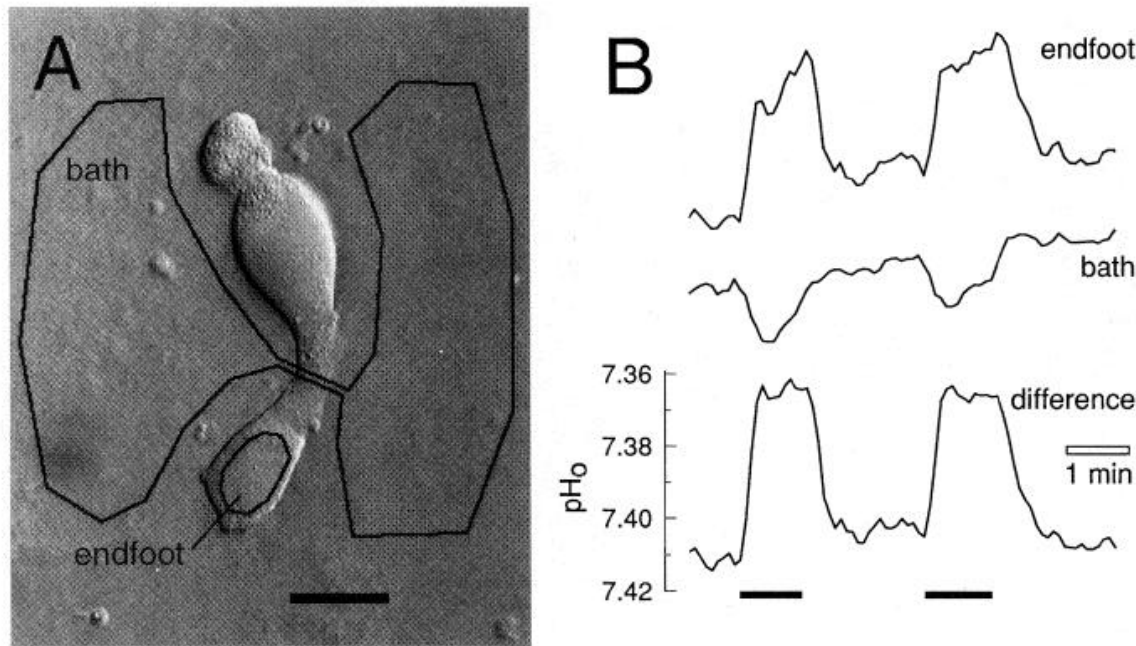

\section{External carbonic anhydrase}

Inhibition of $\mathrm{CA}$ enhanced the extracellular acidification evoked by raising $\left[\mathrm{K}^{+}\right]_{0}$ to $50 \mathrm{~mm}$. Addition of $2 \times 10^{-5} \mathrm{M}$ benzolamide, a potent CA inhibitor (Maren, 1967), increased the $\mathrm{K}^{+}$-evoked acidification to $269 \pm 141 \%$ (8) of the control increase (Fig. 6A). Benzolamide is charged at physiological $\mathrm{pH}$ and is poorly membrane permeant (Travis et al., 1963). It is ineffective in inhibiting intracellular CA in Müller cells (Newman, 1994). Thus, it is likely that benzolamide is acting on extracellular CA in its enhancement of the extracellular acidification. The CA inhibitor methazolamide, which can act on both intracellular and extracellular forms of the enzyme (Maren, 1967), enhanced the $\mathrm{K}^{+}$-evoked extracellular acidification to the same degree as did benzolamide. All subsequent experiments monitoring $\mathrm{pH}_{\mathrm{o}}$ were conducted in the presence of either benzolamide or methazolamide.

\section{$\mathrm{Na}^{+} / \mathrm{HCO}_{3}^{-}$cotransport}

If the $\mathrm{K}^{+}$-induced extracellular acidification is generated solely by the cotransporter, the response should be abolished by removal of $\mathrm{HCO}_{3}^{-}$from the bath solution and by addition of the cotransporter blocker DIDS. This proved to be the case.

Extracellular acidification evoked by raising $\left[\mathrm{K}^{+}\right]_{\mathrm{o}}$ to $50 \mathrm{~mm}$ was reduced to $7.0 \pm 7.9 \%$ (6) of the control amplitude when the $\mathrm{HCO}_{3}^{-}$Ringer's was replaced with HEPES Ringer's (Fig. 6B). Similarly, the addition of $0.5 \mathrm{~mm}$ DIDS reduced the $\mathrm{K}^{+}$-evoked acidification to $7.8 \pm 8.9 \%$ (5) of the control response (Fig. $6 \mathrm{C}$ ).

\section{Localization of $\mathrm{Na}^{+} / \mathrm{HCO}_{3}^{-}$cotransport with $\mathrm{pH}_{\mathrm{o}}$ measurements}

If cotransporter sites are preferentially localized to the endfoot of Müller cells, then $\mathrm{K}^{+}$-induced extracellular acidification should be larger beneath the endfoot than beneath the soma. This proved to be true (Fig. 7A). The endfoot acidifications averaged $304 \pm$ $119 \%$ (12) of the soma responses.

Regional variations in extracellular acidification also were evaluated by calculating difference ratio images. Images of BCECF fluorescence were obtained during control periods and during periods when the $\mathrm{Na}^{+} / \mathrm{HCO}_{3}^{-}$cotransporter was modulated by raising $\left[\mathrm{K}^{+}\right]_{\mathrm{o}}$ to $50 \mathrm{~mm}$. The ratio images, calculated by dividing control by test images, reveal local changes in $\mathrm{pH}_{\mathrm{o}}$ produced by cell stimulation.

Difference ratio images evoked by $\mathrm{K}^{+}$stimulation consistently showed that extracellular acidification was largest beneath the endfoot (Fig. 7C). The endfoot acidification was always greatest in the center of the endfoot and declined toward the edge of the cell, as expected if the acidification was being reduced by diffusion to the bulk solution.

Both temporal plots of $\mathrm{pH}_{\mathrm{o}}$ changes (Fig. $7 A$ ) and difference ratio images of $\mathrm{pH}_{\mathrm{o}}$ changes (Fig. $7 C$ ) confirm previous findings (Newman and Astion, 1991; Newman, 1991) showing that $\mathrm{Na}^{+} /$ $\mathrm{HCO}_{3}^{-}$cotransporter sites are preferentially localized to the cell endfoot. One must be cautious when interpreting the $\mathrm{pH}_{\mathrm{o}}$ results in a quantitative fashion, however, because several factors other than transporter density can influence the magnitude of extracellular acidification beneath a cell. Regional differences in $\mathrm{pH}_{\mathrm{o}}$ could be because of variations in the space between cell and coverslip or the rate at which acid/base equivalents are cleared from beneath the cell. At a first approximation, however, these factors should not differ substantially in different cell regions.

\section{DISCUSSION}

\section{$\mathrm{Na}^{+} / \mathrm{HCO}_{3}^{-}$cotransport}

The results presented in this paper demonstrate that the $\mathrm{Na}^{+} /$ $\mathrm{HCO}_{3}^{-}$cotransport system of salamander Müller cells modulates intracellular and extracellular $\mathrm{pH}$ in response to changes in $\left[\mathrm{K}^{+}\right]_{\mathrm{o}}$. Increasing $\left[\mathrm{K}^{+}\right]_{\mathrm{o}}$ results in an intracellular alkalinization and in an extracellular acidification. The extracellular acidification seems to be generated exclusively by the cotransport system, whereas a large fraction (but not all) of the intracellular alkalinization is generated by the cotransporter.

Previous electrophysiological findings demonstrated that amphibian Müller cells possess a Na ${ }^{+} / \mathrm{HCO}_{3}^{-}$cotransporter (Newman and Astion, 1991; Newman, 1991). In these earlier studies, cotransporter currents were recorded using the whole-cell voltage-clamp technique. The currents were $\mathrm{HCO}_{3}^{-}$- and $\mathrm{Na}^{+}$-dependent and were inhibited by DIDS, 4,4' -dinitrostilbene-2,2' -disulphonic acid (DNDS), and harmaline. The present results confirm the presence of the cotransporter in Müller cells. The observed $\mathrm{K}^{+}$-evoked $\mathrm{pH}$ changes are generated by the cotransporter, inasmuch as they are $\mathrm{HCO}_{3}^{-}$-dependent and DIDS-sensitive.

$\mathrm{Na}^{+} / \mathrm{HCO}_{3}^{-}$cotransport activity is present in other glial cells, including astrocytes in gliotic rat hippocampal slices (Grichtchenko and Chesler, 1994a,b), cultured mammalian astrocytes (Boyarsky et al., 1993; Brookes and Turner, 1994; Brune et al., 1994; O'Connor et al., 1994; Shrode and Putnam, 1994) and oligodendrocytes (Kettenmann and Schlue, 1988), glial cells of the amphibian optic nerve (Astion and Orkand, 1988), and neuropil 

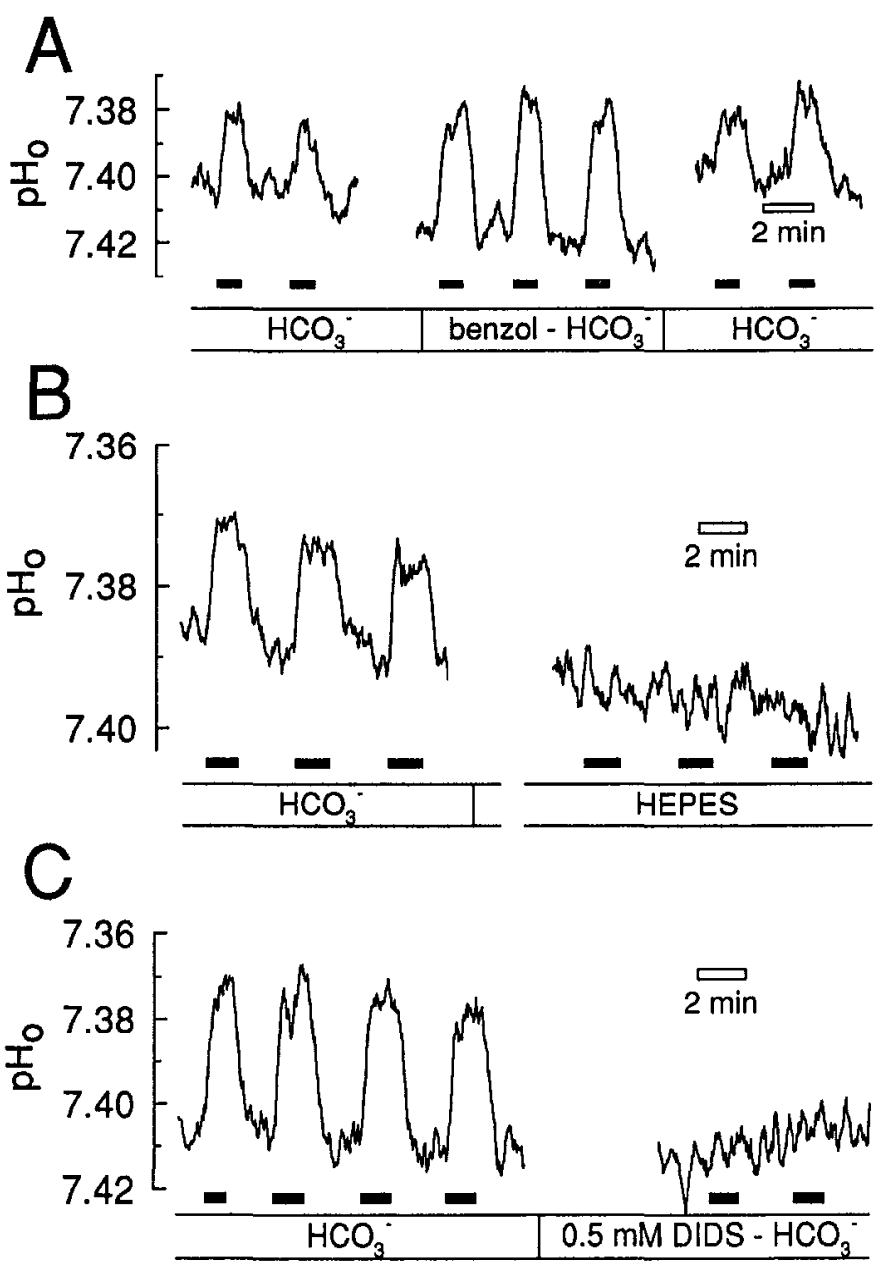

Figure 6. Potassium-evoked extracellular acidification. $A$, Addition of $2 \times 10^{-5} \mathrm{M}$ benzolamide (benzol), a CA inhibitor, increases the amplitude of the acidification in this example to $199 \%$ of control. When benzolamide is removed, the acidification returns to control amplitude. The shift in baseline $\mathrm{pH}_{\mathrm{o}}$ during benzolamide application reflects drift in the measurement of $\mathrm{pH}$ and is not caused by benzolamide. $\mathrm{pH}_{0}$ is measured beneath the endfoot. Gaps in the record before and after benzolamide are 2.6 and 10.7 min in length. $B$, Substitution of HEPES for $\mathrm{HCO}_{3}^{-}$Ringer's diminishes the $\mathrm{K}^{+}$-evoked extracellular acidification to near zero. $\mathrm{pH}_{\mathrm{o}}$ is measured beneath the endfoot. There is a $28.7 \mathrm{~min}$ gap in the record. $C$, Addition of $0.5 \mathrm{~mm}$ DIDS diminishes the acidification to near zero. $\mathrm{pH}_{\mathrm{o}}$ is measured beneath the endfoot. There is a 6 min gap in the record.

glia of the leech (Deitmer and Schlue, 1989; Deitmer and Szatkowski, 1990; Munsch and Deitmer, 1994).

\section{Extracellular acidification}

The present results lend support to previous studies which have shown that glial cells contribute to $\mathrm{pH}_{\mathrm{o}}$ changes in the CNS. In the enucleated rat optic nerve, which contains only glial cells, increased $\left[\mathrm{K}^{+}\right]_{\mathrm{o}}$ generates an extracellular acidification (Ransom et al., 1988). In the gliotic rat hippocampal slice, where few neurons are present, elevation of $\left[\mathrm{K}^{+}\right]_{0}$ results in extracellular acidification as well (Grichtchenko and Chesler, 1994a,b). The acidification is $\mathrm{Na}^{+}$- and $\mathrm{HCO}_{3}^{-}$-dependent, suggesting that it is generated by activation of a glial $\mathrm{Na}^{+} / \mathrm{HCO}_{3}^{-}$cotransporter. In addition, dissociated amphibian Müller cells, when stimulated with glutamate, generate an extracellular alkalinization arising from a glutamate uptake carrier that transports either $\mathrm{OH}$ or $\mathrm{HCO}_{3}^{-}$out of cells as glutamate is transported in (Bouvier et al., 1992).
Other studies have also linked extracellular acidification to glial cells. In developmental studies of the rat uptic nerve (Ransom et al., 1988) and spinal cord (Sykova et al., 1992a,b), increases in the amplitude of stimulus-evoked extracellular acidification parallel the proliferation and maturation of glial cells. In the spinal cord, a rapid extracellular acidification seems to be generated by a 4-acetamido-4'-isothiocyanato-stilbene-2,2'-disulfonic acid (SITS)sensitive $\mathrm{Na}^{+} / \mathrm{HCO}_{3}^{-}$cotransport system (Sykova and Svoboda, 1990; Sykova et al., 1992b). In the neonatal rat spinal cord, $x-$ irradiation leads to the disruption of normal glial development and to the loss of stimulus-evoked extracellular acidification (Sykova et al., 1992a). In the rat cortex in vivo, electrical stimulation results in glial cell alkalinization, which is correlated with cell depolarization (Chesler and Kraig, 1989). A DIDS-sensitive, stimulus-evoked extracellular acidification, generated by a $\mathrm{Na}^{+} / \mathrm{HCO}_{3}^{-}$cotransporter, also is observed in neuropil glial cells of the leech segmental ganglion (Rose and Deitmer, 1994, 1995a,b).

In the present experiments, elevated $\left[\mathrm{K}^{+}\right]_{\mathrm{o}}$ resulted in an acidification ranging from 0.01 to $0.05 \mathrm{pH}$ units in amplitude. Because conditions differ markedly between the in vitro preparation used here and in vivo conditions, it is difficult to estimate the magnitude of a Müller cell acidification in the intact retina. On one hand, $\left[\mathrm{K}^{+}\right]_{\mathrm{o}}$ increases observed in vivo are much smaller than those used here $(\sim 0.5 \mathrm{~mm}$ vs $50 \mathrm{~mm})$. On the other hand, clearance of the acidification will be less efficient in vivo, where cells are packed close together, than in the experimental preparation, where the acidification is rapidly cleared to the bulk solution by diffusion.

An estimate of the magnitude of a Müller cell-generated acidification in vivo can be made, however. $\mathrm{A}\left[\mathrm{K}^{+}\right]_{\mathrm{o}}$ increase of $0.5 \mathrm{~mm}$ will generate a driving force for $\mathrm{HCO}_{3}^{-}$influx $\sim 19$ times smaller that that generated by a $50 \mathrm{~mm}$ increase. If one assumes that diffusional clearance of the acidification occurs at one-tenth the rate and that the intercellular spacing is half of its value in vitro, then a $0.5 \mathrm{~mm}\left[\mathrm{~K}^{+}\right]_{\mathrm{o}}$ increase will generate an acidification of approximately the same amplitude as observed in this study.

\section{Localization of cotransporter to endfoot}

$\mathrm{pH}$ measurements confirm that $\mathrm{Na}^{+} / \mathrm{HCO}_{3}^{-}$cotransporter sites are localized preferentially to the endfoot in salamander Müller cells. In earlier voltage-clamp studies, cotransporter currents recorded at the endfoot were 6.5-fold greater than those recorded at the soma (Newman and Astion, 1991; Newman, 1991). In the present study, difference ratio images of $\mathrm{K}^{+}$-evoked $\mathrm{pH}_{\mathrm{o}}$ acidification (Fig. $7 \mathrm{C}$ ) graphically demonstrate this localization, as do $\mathrm{pH}_{\mathrm{i}}$ measurements of $\mathrm{K}^{+}$-evoked alkalinization in cells with and without endfeet.

\section{$\mathrm{HCO}_{3}^{-}$-independent intracellular alkalinization}

Approximately $40 \%$ of the $\mathrm{K}^{+}$-evoked intracellular alkalinization observed in the present study is $\mathrm{HCO}_{3}^{-}$-independent and DIDSinsensitive and is presumably generated by a mechanism other than $\mathrm{Na}^{+} / \mathrm{HCO}_{3}^{-}$cotransport. The alkalinization apparently is not attributable to transmembrane acid/base transport, as only 7-8\% of the $\mathrm{K}^{+}$-evoked extracellular acidification is $\mathrm{HCO}_{3}^{-}$-independent and DIDS-insensitive. A similar cotransporter-independent intracellular alkalinization has been observed in astrocytes in gliotic hippocampal slices (Grichtchenko and Chesler, 1994a). The alkalinization may be attributable to a $\mathrm{K}^{+}$-evoked change in the metabolic state of the cell (Orkand et al., 1973; Salem et al., 1975), although the specific pathways that are involved remain unknown. 

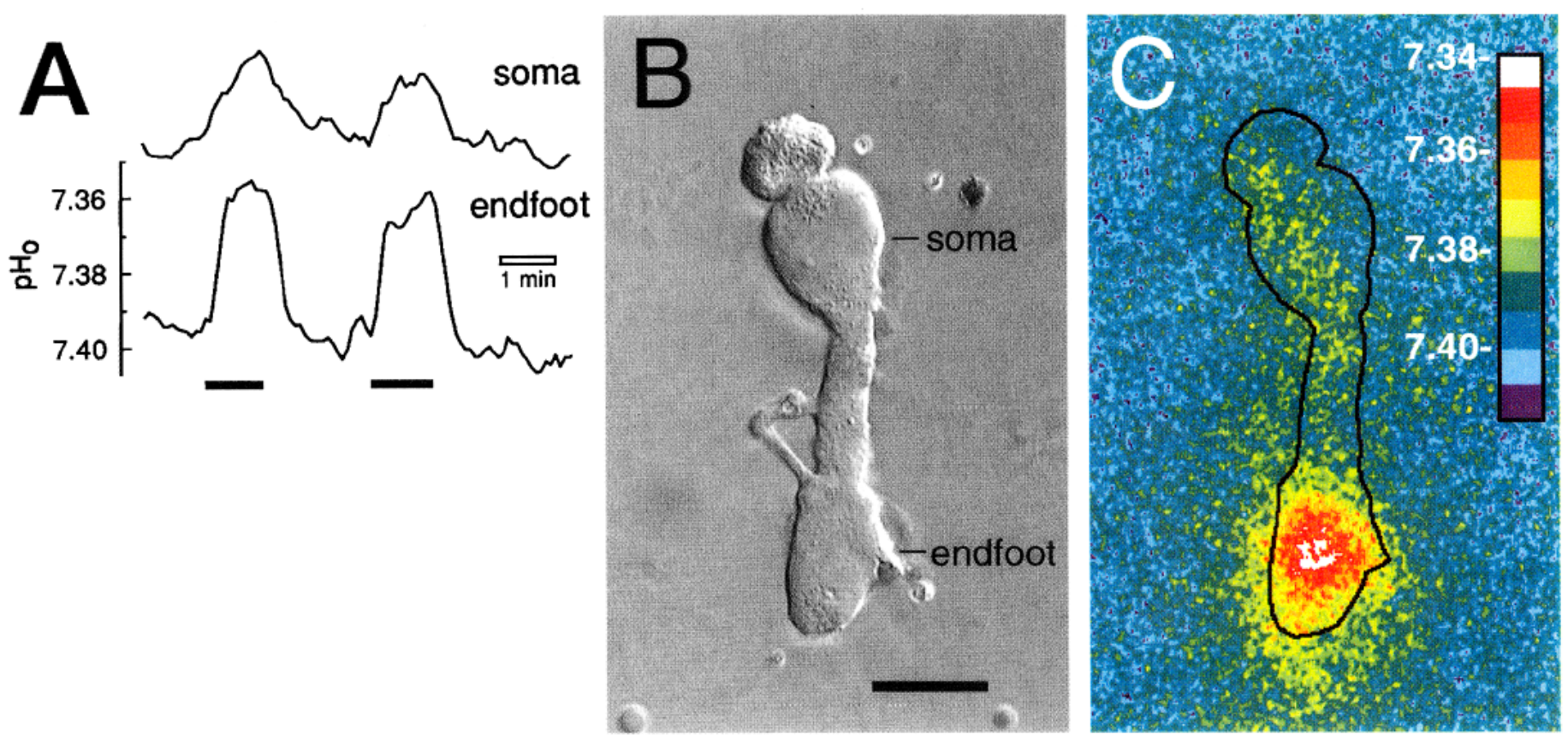

Figure 7. The amplitude of the $\mathrm{K}^{+}$-evoked extracellular acidification is greater at the endfoot than at the soma. $A, \mathrm{pH}_{\mathrm{o}}$ is recorded simultaneously beneath the endfoot and soma of a single cell in $\mathrm{HCO}_{3}^{-}$Ringer's. The amplitude of the endfoot response in this example is $238 \%$ of the amplitude of the soma response. The soma record has been displaced vertically. $B$, Nomarski micrograph of a dissociated Müller cell. Scale bar, $20 \mu \mathrm{m}$. $C$, Difference ratio image of $\mathrm{pH}_{\mathrm{o}}$ changes evoked by raising $\left[\mathrm{K}^{+}\right]_{\mathrm{o}}$ from 2.5 to $50 \mathrm{~mm}$ in $\mathrm{HCO}_{3}^{-}$Ringer's. The image is of the same field as shown in $B$, with the position of the cell indicated by the outline. Increasing $\left[\mathrm{K}^{+}\right]_{0}$ evokes an acidification that is largest beneath the endfoot (peak magnitude, $0.054 \mathrm{pH}$ units) and small beneath other cell regions. $\mathrm{pH}_{\mathrm{o}}$ is indicated by the color calibration bar in this pseudocolor image.

A $\mathrm{HCO}_{3}^{-}$-independent, $\mathrm{K}^{+}$-evoked intracellular alkalinization attributable to a bafilomycin $\mathrm{A}_{1}$-sensitive $\mathrm{H}^{+}$-ATPase has been reported in cultured mammalian astrocytes (Pappas and Ransom, 1993). It is unlikely that a $\mathrm{H}^{+}$-ATPase contributes significantly to the $\mathrm{HCO}_{3}^{-}$-independent intracellular alkalinization in Müller cells, however, because $\mathrm{H}^{+}$-ATPase activation would generate an extracellular acidification.

\section{External carbonic anhydrase}

The experiments presented here provide evidence that salamander Müller cells possess extracellular CA activity. Addition of the extracellular CA inhibitor benzolamide at $2 \times 10^{-5} \mathrm{M}$ produces a $169 \%$ increase in the $\mathrm{K}^{+}$-evoked extracellular acidification. It is unlikely that benzolamide is exerting its effect by inhibiting an internal component of CA; I have shown previously that benzolamide, at a higher concentration of $10^{-4} \mathrm{M}$, is ineffective in inhibiting intracellular CA (Newman, 1994).

It is possible that benzolamide is acting not on a native membrane-bound CA but on an enzyme contained in cell fragments adhering to dissociated cells. This is unlikely, as the dissociation procedure yields cells free of visible debris. It also is unlikely that intracellular CA is leaking out from dissociated cells; these cells maintain their integrity for many hours, as judged by electrophysiological criteria.

Numerous studies have demonstrated the importance of extracellular CA in reducing activity-dependent $\mathrm{pH}_{\mathrm{o}}$ variations in the CNS. The addition of CA inhibitors results in enhancement of these $\mathrm{pH}_{\mathrm{o}}$ variations (Borgula et al., 1989; Sykova and Svoboda, 1990; Chen and Chesler, 1992a; Grichtchenko and Chesler, 1994b; Rose and Deitmer, 1995a) and can modulate neuronal activity (Taira et al., 1993; Gottfried and Chesler, 1994). The results presented here demonstrate that Müller cells contribute to extracellular CA activity in the retina. This extracellular CA may help to regulate $\mathrm{pH}_{\mathrm{o}}$ variations in the retina; previous studies have demonstrated that retinal, light-evoked $\mathrm{pH}_{\mathrm{o}}$ transients are enhanced by the addition of CA inhibitors (Borgula et al., 1989; Oakley and Wen, 1989).

CA modulates $\mathrm{pH}_{\mathrm{o}}$ variations because it catalyzes the reaction

$$
\mathrm{CO}_{2}+\mathrm{H}_{2} \mathrm{O} \stackrel{\mathrm{CA}}{\longleftrightarrow} \mathrm{H}_{2} \mathrm{CO}_{3} \leftrightarrow \mathrm{H}^{+}+\mathrm{HCO}_{3}^{-},
$$

which is the basis of $\mathrm{pH}_{\mathrm{o}}$ buffering in the CNS (Chesler, 1990). The effective buffering power of the $\mathrm{CO}_{2} / \mathrm{HCO}_{3}^{-}$system for rapid changes in $\mathrm{pH}_{\mathrm{o}}$ is substantially greater when $\mathrm{CA}$ is present. It is not clear, however, whether modulation of the $\mathrm{CO}_{2} / \mathrm{HCO}_{3}^{-}$buffer system accounts for the benzolamide enhancement of the extracellular acidification observed in the present study. Activation of the $\mathrm{Na}^{+} / \mathrm{HCO}_{3}^{-}$cotransporter is thought to lead to an influx of $\mathrm{HCO}_{3}^{-}$into Müller cells and to a reduction in $\left[\mathrm{HCO}_{3}^{-}\right]_{\mathrm{o}}$. This decrease in $\left[\mathrm{HCO}_{3}^{-}\right]_{\mathrm{o}}$ generates an extracellular acidification that should be reduced, rather than increased, by the action of a CA inhibitor (Grichtchenko and Chesler, 1994a,b). Elucidation of the mechanism by which benzolamide enhances the $\mathrm{K}^{+}$-evoked extracellular acidification awaits additional study.

\section{Significance of extracellular acidification Neutralization of extracellular alkalinization}

Neuronal activity often is associated with a transient extracellular alkalinization, which is generated by glutamatergic and GABAergic receptors (Chesler, 1990; Chesler and Kaila, 1992). Calcium channels at synaptic terminals are $\mathrm{pH}$-dependent (Barnes and Bui, 1991; Barnes et al., 1993; Takahashi et al., 1993), and the extracellular alkalinization, by increasing $\mathrm{Ca}^{2+}$ conductance, leads to enhanced synaptic transmission (Balestrino and Somjen, 1988; 
Barnes et al., 1993). The extracellular acidification generated by glial cells, demonstrated in this and other studies, may function to partially balance this fast alkalinization thus minimizing changes in synaptic cfficacy. In a similar manner, acid cfflux from glia could serve as a component of a negative feedback system, regulating neuronal activity (Ransom, 1992). As neuronal activity increases, raising $\left[\mathrm{K}^{+}\right]_{0}$ and depolarizing glial cells, the acidification produced by the glial $\mathrm{Na}^{+} / \mathrm{HCO}_{3}^{-}$cotransporter will reduce the conductance of neuronal ion channels and depress neuronal excitability.

In the retina, light stimulation produces an extracellular alkalinization in the inner plexiform (synaptic) layer and in the photoreceptor layer (Borgula et al., 1989; Yamamoto et al., 1992). Modulation of the Müller cell $\mathrm{Na}^{+} / \mathrm{HCO}_{3}^{-}$cotransporter, generating an extracellular acidification, may help to counter this alkalinization.

\section{Regulation of blood flow}

In both the retina (Riva et al., 1991; Scheiner et al., 1994) and the brain (Roy and Sherrington, 1890; Fox and Raichle, 1984), increases in neuronal activity result in increased blood flow. I have proposed previously that glial cells mediate this homeostatic response by releasing acid equivalents onto blood vessels (Newman, 1991). (Vessels are $\mathrm{pH}$-sensitive and dilate when $\mathrm{pH}_{\mathrm{o}}$ acidifies; McCulloch et al., 1982.) The endfeet of both Müller cells and astrocytes terminate directly onto blood vessels in the CNS. The demonstration that increased $\left[\mathrm{K}^{+}\right]_{0}$ results in an extracellular acidification and particularly that this acidification is preferentially localized to cell endfeet provides support for this hypothesis of glial cell regulation of blood flow.

\section{REFERENCES}

Astion ML, Orkand RK (1988) Electrogenic $\mathrm{Na}^{+} / \mathrm{HCO}_{3}^{-}$cotransport in neuroglia. Glia 1:355-357.

Balestrino M, Somjen GG (1988) Concentration of carbon dioxide, interstitial $\mathrm{pH}$ and synaptic transmission in hippocampal formation of the rat. J Physiol (Lond) 396:247 266.

Barnes S, Bui Q (1991) Modulation of calcium-activated chloride current via $\mathrm{pH}$-induced changes of calcium channel properties in cone photoreceptors. J Neurosci 11:4015-4023.

Barnes S, Merchant V, Mahmud F (1993) Modulation of transmission gain by protons at the photoreceptor output synapse. Proc Natl Acad Sci USA 90:10081-10085.

Borgula GA, Karwoski CJ, Steinberg RH (1989) Light-evoked changes in extracellular $\mathrm{pH}$ in frog retina. Vision Res 29:1069-1077.

Boron WF, Boulpaep EL (1983) Intracellular pH regulation in the renal proximal tubule of the salamander. Basolateral $\mathrm{HCO}_{3}^{-}$transport. J Gen Physiol 81:53-94.

Boron WF, Boulpaep EL (1989) The electrogenic $\mathrm{Na} / \mathrm{HCO}_{3}$ cotransporter. Kidney Int 36:392-402.

Bouvier M, Szatkowski M, Amato A, Attwell D (1992) The glial cell glutamate uptake carrier countertransports $\mathrm{pH}$-changing anions. Nature 360:471-474.

Boyarsky G, Ransom B, Schlue W-R, Davis MBE, Boron WF (1993) Intracellular $\mathrm{pH}$ regulation in single cultured astrocytes from rat forebrain. Glia 8:241-248.

Brookes N, Turner RJ (1994) $\mathrm{K}^{+}$-induced alkalinization in mouse cerebral astrocytes mediated by reversal of electrogenic $\mathrm{Na}^{+}-\mathrm{HCO}_{3}^{-}$cotransport. Am J Physiol 267:C1633-C1640.

Brune T, Fetzer S, Backus KH, Deitmer JW (1994) Evidence for electrogenic sodium-bicarbonate cotransport in cultured rat cerebellar astrocytes. Pflügers Arch 429:64-71.

Chen JCT, Chesler M (1992a) pH transients evoked by excitatory synaptic transmission are increased by inhibition of extracellular carbonic anhydrase. Proc Natl Acad Sci USA 89:7786-7790.

Chen JCT, Chesler M (1992b) Modulation of extracellular $\mathrm{pH}$ by glutamate and GABA in rat hippocampal slices. J Neurophysiol 67:29-36.

Chesler M (1990) The regulation and modulation of $\mathrm{pH}$ in the nervous system. Prog Neurobiol 34:401-427.
Chesler M, Kaila K (1992) Modulation of $\mathrm{pH}$ by neuronal activity. Trends Neurosci 15:396-402.

Chesler M, Kraig RP (1989) Intracellular pH transients of mammalian astrocytes. J Neurosci 9:2011-2019.

Deitmer JW, Schlue WR (1989) An inwardly directed electrogenic sodium-bicarbonate cotransport in leech glial cells. J Physiol (Lond) 411:179-194.

Deitmer JW, Szatkowski M (1990) Membrane potential dependence of intracellular $\mathrm{pH}$ regulation by identified glial cells in the leech central nervous system. J Physiol (Lond) 421:617-631.

Fox PT, Raichle ME (1984) Stimulus rate dependence of regional cerebral blood flow in human striate cortex, demonstrated by positron emission tomography. J Neurophysiol 51:1109-1120.

Gottfried JA, Chesler M (1994) Endogenous $\mathrm{H}^{+}$modulation of NMDA receptor-mediated EPSCs revealed by carbonic anhydrase inhibition in rat hippocampus. J Physiol (Lond) 478:373-378.

Grichtchenko II, Chesler M (1994a) Depolarization-induced alkalinization of astrocytes in gliotic hippocampal slices. Neuroscience 62:1071-1078.

Grichtchenko II, Chesler M (1994b) Depolarization-induced acid secretion in gliotic hippocampal slices. Neuroscience 62:1057-1070.

Harsanyi K, Mangel SC (1993) Modulation of cone to horizontal cell transmission by calcium and $\mathrm{pH}$ in the fish retina. Vis Neurosci 10:81-91.

Hughes BA, Adorante JS, Miller SS, Lin H (1989) Apical electrogenic $\mathrm{NaHCO}_{3}$ cotransport. A mechanism for $\mathrm{HCO}_{3}$ absorption across the retinal pigment epithelium. J Gen Physiol 94:125-150.

Jarolimek W, Misgeld U, Lux HD (1989) Activity dependent alkaline and acid transients in guinea pig hippocampal slices. Brain Res 505:225-232.

Kaila K, Paalasmaa P, Taira T, Voipio J (1992) $\mathrm{pH}$ transients due to monosynaptic activation of $\mathrm{GABA}_{\mathrm{A}}$ receptors in rat hippocampal slices. NeuroReport 3:105-108.

Kettenmann H, Schlue WR (1988) Intracellular pH regulation in cultured mouse oligodendrocytes. J Physiol (Lond) 406:147-162.

Kleinschmidt J (1994) Signal transmission at the photoreceptor synapse. Role of calcium ions and protons. $\Lambda \mathrm{nn}$ NY $\Lambda$ cad Sci 468-470.

Klockner U, Isenberg G (1994) Calcium channel current of vascular smooth muscle cells: extracellular protons modulate gating and single channel conductance. J Gen Physiol 103:665-678.

Krafte DS, Kass RS (1988) Hydrogen ion modulation of Ca channel current in cardiac ventricular cells. J Gen Physiol 91:641-657.

Maren TH (1967) Carbonic anhydrase: chemistry, physiology, and inhibition. Physiol Rev 47:597-781.

McCulloch J, Edvinsson L, Watt P (1982) Comparison of the effects of potassium and $\mathrm{pH}$ on the calibre of cerebral veins and arteries. Pflügers Arch 393:95-98.

Munsch T, Deitmer JW (1994) Sodium-bicarbonate cotransport current in identified leech glial cells. J Physiol (Lond) 474:43-53.

Newman EA (1985) Membrane physiology of retinal glial (Müller) cells. J Neurusci 5:2225-2239.

Newman EA (1991) Sodium-bicarbonate cotransport in retinal Müller (glial) cells of the salamander. J Neurosci 11:3972-3983.

Newman EA (1994) A physiological measure of carbonic anhydrase in Müller cells. Glia 11:291-299.

Newman EA, Astion ML (1991) Localization and stoichiometry of electrogenic sodium-bicarbonate cotransport in retinal glial cells. Glia 4:424-428.

Nicholson C, Phillips JM (1981) Ion diffusion modified by tortuosity and volume fraction in the extracellular microenvironment of the rat cerebellum. J Physiol 321:225-257.

Oakley BI, Wen R (1989) Extracellular pH in the isolated retina of the toad in darkness and during illumination. J Physiol (Lond) 419:353-378.

O'Connor ER, Sontheimer H, Ransom BR (1994) Rat hippocampal astrocytes exhibit electrogenic sodium-bicarbonate cotransport. J Neurophysiol 72:2580-2589.

Orkand PM, Bracho H, Orkand RK (1973) Glial metabolism: alteration by potassium levels comparable to those during neural activity. Brain Res 55:467-471.

Pappas CA, Ransom BR (1993) A depolarization-stimulated, bafilomycin-inhibitable $\mathrm{H}^{+}$-pump in hippocampal astrocytes. Glia 9:280-291.

Prod'hom B, Pietrobon D, Hess P (1987) Direct measurement of proton transfer rates to a group controlling the dihydropyridine-sensitive $\mathrm{Ca}^{2+}$ channel. Nature 329:243-246.

Ransom BR (1992) Glial modulation of neural excitability mediated by extracellular pH: a hypothesis. Prog Brain Res 94:37-46.

Ransom BR, Carlini WG, Connors BW (1988) Brain extracellular space: developmental studies in rat optic nerve. Ann NY Acad Sci 481:87-105. 
Riva CE, Harino S, Shonat RD, Petrig BL (1991) Flicker evoked increase in optic nerve head blood flow in anesthetized cats. Neurosci Lett 128:291-296.

Rose CR, Deitmer JW (1994) Evidence that glial cells modulate extracellular $\mathrm{pH}$ transients induced by neuronal activity in the leech central nervous system. J Physiol 481:1-5.

Rose CR, Deitmer JW (1995a) Stimulus-evoked changes of extra- and intracellular $\mathrm{pH}$ in the leech central nervous system. II. Mechanisms and maintenance of $\mathrm{pH}$ homeostasis. J Neurophysiol 73:132-140.

Rose CR, Deitmer JW (1995b) Stimulus-evoked changes of extra- and intracellular $\mathrm{pH}$ in the leech central nervous system. I. Bicarbonate dependence. J Neurophysiol 73:125-131.

Roy CS, Sherrington CS (1890) On the regulation of the blood-supply of the brain. J Physiol (Lond) 11:85-108.

Salem RD, Hammerschlag R, Bracho H, Orkand RK (1975) Influence of potassium ions on accumulation and metabolism of $\left[{ }^{14} \mathrm{C}\right]$ glucose by glial cells. Brain Res 86:499-503.

Scheiner AJ, Riva CE, Kazahaya K, Petrig BL (1994) Effect of flicker on macular blood flow assessed by the blue field simulation technique. Invest Ophthalmol Vision Sci 35:3436-3441.

Shrode LD, Putnam RW (1994) Intracellular $\mathrm{pH}$ regulation in primary rat astrocytes and C6 glioma cells. Glia 12:196-210.

Soleimani M, Grassl SM, Aronson PS (1987) Stoichiometry of $\mathrm{Na}^{-}-$ $\mathrm{HCO}_{3}^{-}$cotransport in basolateral membrane vesicles isolated from rabbit renal cortex. J Clin Invest 79:1276-1280.

Sykova E, Jendelova P, Simonova Z, Chvatal A (1992a) $\mathrm{K}^{+}$and $\mathrm{pH}$ homeostasis in the developing rat spinal cord is impaired by early postnatal X-irradiation. Brain Res 594:19-30.
Sykova E, Jendelova P, Svoboda J, Chvatal A (1992b) Extracellular K ${ }^{+}$, $\mathrm{pH}$, and volume changes in spinal cord of adult rats and during postnatal development. Can J Physiol Pharmacol 70:S301-S309.

Sykova E, Svoboda J (1990) Extracellular alkaline-acid-alkaline transients in the rat spinal cord evoked by peripheral stimulation. Brain Res 512:181-189.

Taira T, Smirnov S, Voipio J, Kaila K (1993) Intrinsic proton modulation of excitatory transmission in rat hippocampal slices. NeuroReport 4:93-96.

Takahashi K, Dixon DB, Copenhagen DR (1993) Modulation of a sustained calcium current by intracellular $\mathrm{pH}$ in horizontal cells of fish retina. J Gen Physiol 101:695-714.

Tang C-M, Dichter M, Morad M (1990) Modulation of the $N$-methyl-Daspartate channel by extracellular $\mathbf{H}^{+}$. Proc Natl Acad Sci USA 87:6445-6449.

Travis DM, Wilcy C, Nechay BR, Maren TII (1963) Selective renal carbonic anhydrase inhibition without respiratory effect: pharmacology of 2-benzenesulfonamido-1,3,1-thiadiazole-5-sulfonamide (CL 11,366). J Pharmacol Exp Ther 143:383-394.

Traynelis SF, Cull-Candy SG (1990) Proton inhibition of $N$-methyl-Daspartate receptors in cerebellar neurons. Nature 345:347-350.

Voipio J, Kaila K (1993) Interstitial $\mathrm{P}_{\mathrm{CO}_{2}}$ and $\mathrm{pH}$ in rat hippocampal slices measured by means of a novel fast $\mathrm{CO}_{2} / \mathrm{H}^{+}$-sensitive microelectrode based on a PVC-gelled membrane. Pflügers Arch 423:193-201.

Yamamoto F, Borgula GA, Steinberg RH (1992) Effects of light and darkness on $\mathrm{pH}$ outside rod photoreceptors in the cat retina. Exp Eye Res 54:685-697. 